\title{
Abnormal uterine bleeding as a presenting symptom is related to multiple uterine leiomyoma: an ultrasound-based study
}

This article was published in the following Dove Press journal:

International Journal of Women's Health

24 October 2013

Number of times this article has been viewed

\author{
José Alberto Fonseca- \\ Moutinho ${ }^{1,2}$ \\ Lígia Silva Barbosa' \\ Daniel Gonçalves Torres' \\ Sara Morgado Nunes ${ }^{3}$
}

'Faculty of Health Sciences, School of Medicine, Beira Interior University, Covilhã, Portugal; ${ }^{2}$ Child and Women Department, Cova da Beira Academic Medical Center, Covilhã, Portugal; ${ }^{3}$ Polytechnic Institute of Castelo Branco, Castelo Branco, Portugal
Correspondence: José Alberto Fonseca-Moutinho

Avenida Infante D Henrique 6200-506 Covilhã, Portugal

$\mathrm{Tel}+351917295400$

Fax +351249718430

Email jafmoutinho@fcsaude.ubi.pt
Purpose: To determine the prevalence of uterine leiomyomas, diagnosed by ultrasound, in a private health care setting located in the central eastern region of Portugal, and to explore the demographic and clinical factors related to diagnosis and symptomatology.

Patients and methods: The files of 624 patients attending a private clinic in Covilhã, Portugal, from January 2 to December 31, 2010 were retrieved for evaluation. Pelvic ultrasound record, age, weight, height, age at menarche, number of pregnancies and deliveries, marital status, menstrual cycles characteristic, and contraceptive method at consultation were included in the analysis. Results: Uterine leiomyoma (UL) was diagnosed by ultrasonography in 161 (25.8\%) patients. A single UL was diagnosed in 80 (49.7\%) patients. In 79 (49.1\%) patients, the largest leiomyoma had a dimension $<20 \mathrm{~mm}$. Prevalence of UL was age dependent: at $11.0 \%$ for women 20-39 years old; $45.4 \%$ for those aged $40-59$ years; and $19.5 \%$ for women 60 years or older. Metrorrhagia was the most distressing presenting symptom. When menorrhagia was the presenting symptom, the probability of having an ultrasound diagnosis of UL was $73.3 \%$. Metrorrhagia or menorrhagia, as presenting symptom, was significantly related to the ultrasound diagnosis of multiple ULs.

Conclusion: UL was especially prevalent in women aged between 40 and 59 years. Patients with multiple ULs had significantly more abnormal uterine bleeding. In patients with menorrhagia or metrorrhagia, special attention should be taken in searching for the presence of multiple ULs during ultrasound.

Keywords: fibroid, leiomyoma, prevalence, ultrasound, menorrhagia, metrorrhagia

\section{Introduction}

Leiomyomas, also known as fibroids, are the most frequent benign uterine tumors to develop during a woman's reproductive years; occurrence tends to regress after menopause. ${ }^{1}$ Malign transformation of uterine leiomyoma (UL) seems to be a very rare event, ${ }^{2}$ but they are symptomatic in $20 \%-30 \%$ of cases and are the main reason for approximately one-third of all hysterectomies in developed countries. ${ }^{3,4}$ Symptoms related to UL are menstrual disorders, mainly menorrhagia, pelvic pain, and infertility, which can adversely affect pregnancy outcomes. ${ }^{5,6} \mathrm{UL}$ disproportionately affects Black women. ${ }^{4,7,8}$ The etiology of UL is unknown, but it can be influenced by genetic liability, ${ }^{9}$ hormonal environment, ${ }^{10,11}$ and local tissue mediators. ${ }^{10,12}$ Definitive prevalence of UL in the general female population is also unknown, but differs by ethnicity, age, and method used for diagnosis. ${ }^{13}$ In clinical practice, transvaginal ultrasonography (TVS) is the most widespread method for evaluating UL, with an estimated accuracy of $87 \%-92 \%{ }^{14-16}$ 
The objective of this study was to determine the prevalence of UL, diagnosed by TVS, at a private health care setting located in the central eastern part of Portugal, and to explore the demographic and clinical factors related to diagnosis and symptomatology.

\section{Materials and methods}

The study retrospectively analyzed the medical files of all female patients who consecutively attended a gynecological consultation at a private health care setting located in Covilhã, Portugal, from December 2-31, 2010. Excluded from the study were virgins, patients who had previously undergone a hysterectomy, or those pregnant at the time of the consultation. All included patients were Caucasian, except three, who were African.

The same gynecologist (JAF), who has more than 20 years of gynecological experience and competence in the practice of gynecologic ultrasound, attended all patients.

Policies of the private clinic include recording of demographic and clinical data from every patient in a standard digital database. In all cases, an office TVS was offered to the patient. The sonographic equipment used was a Nemio 17 (SSA-550A) with a PVM-651VT $6 \mathrm{MHz}$ endovaginal probe (Toshiba Corporation, Tokyo, Japan).

For the anonymous use of data from patient files, written consent was obtained from the clinical director of the private health care clinic. LSB and DGT analyzed the files of 624 patients who met the inclusion criteria, and from each file they retrieved age, weight, height, age at menarche, number of pregnancies and deliveries, marital status, menstrual cycles characteristics, and contraceptive method at time of consultation. The presence, number, and largest dimension of the ULs were retrieved from TVS records. For analysis, the data recorded at the first consultation in 2010 were considered. Ultrasound records were analyzed for the presence or absence of UL, their number. location and largest dimension.

The data were organized and analyzed in Statistical Package for the Social Sciences ${ }^{\circledR}$ software ([SPSS] v 20.0 for Windows; IBM Corporation, Armonk, NY, USA), by SMN. Univariate analysis and multivariate logistic regression analysis were performed. In all cases, $P<0.05$ was considered significant.

\section{Results}

Using TVS, UL was diagnosed in 161 (25.8\%) of those 624 cases included in the study. From those 161 patients with an ultrasound-based diagnosis of UL, 99 (61.5\%) had previous knowledge of the disease. In three patients, resectoscopic myomectomy was proposed for treating symptomatic submucous leiomyoma.

The demographic characteristics of the studied population are shown in Table 1. The mean age was 39.6 years; $66.2 \%$ of the women were married; $68.2 \%$ reported having had at least one pregnancy and $64.2 \%$ at least one delivery; $31.6 \%$ were asymptomatic. UL was diagnosed by ultrasound in $11.0 \%$ of all women aged 20 to 39 years old, in $45.4 \%$ of all women aged 40 to 59 years, and in $19.5 \%$ of all women aged 60 years or more. Metrorrhagia and menorrhagia were the most usual presenting symptoms, and were recorded in $11.3 \%$ of all cases and in $22.3 \%$ of all women with an ultrasound diagnosis of UL.

The uterus was explored with clinical bimanual palpation and TVS. Results of clinical and ultrasound exploration of the uterus are shown in Table 2. The overall prevalence of UL was $17.0 \%$ by bimanual palpation and $25.8 \%$ by TVS. ULs larger than $3.0 \mathrm{~cm}$ were identified through ultrasound imaging in $24.2 \%$ of the cases.

In order to uncover significant demographic and clinical differences between women with and without ultrasound diagnosis of UL, a univariate analysis was performed (Table 3). Significant factors associated with an ultrasoundbased diagnosis of UL were the following: 40 to 59 years of age; married; excessive body weight (obese); prior pregnancy or delivery; non-use of the combined pill for contraception; and symptoms of menorrhagia. However, after adjustment by multivariate logistic regression analysis, age 40 to 59 years remained the single demographic and clinical factor found to be statistically associated with ultrasonographic diagnosis of UL.

Menorrhagia, metrorrhagia, and pelvic pain were the most frequent presenting symptoms. When menorrhagia was the presenting symptom, an ultrasound imaging diagnosis of UL was made in $73.3 \%$ of cases (Table 3 ). Plotting a univariate analysis, metrorrhagia and menorrhagia as presenting symptoms were significantly related to the TVS diagnosis of multiple ULs, but not with the largest UL dimension (Tables 4 and 5). Although lacking statistical significance, patients diagnosed with smaller ULs seemed to be more symptomatic (Table 5).

\section{Discussion}

The real prevalence of UL in the general population is unknown. UL prevalence has been evaluated by different methods, such as population surveys, ${ }^{17}$ pathologic study of surgical specimens of hysterectomy, ${ }^{18}$ postmortem of women who died without gynecological diseases, ${ }^{19}$ and 
Table I Demographic characteristics (624 cases)

\begin{tabular}{|c|c|c|c|c|}
\hline \multirow[t]{2}{*}{ Demographic data } & \multicolumn{2}{|c|}{$\begin{array}{l}\text { Total } \\
\text { (624 cases) }\end{array}$} & \multicolumn{2}{|c|}{$\begin{array}{l}\text { Leiomyoma } \\
\text { (161 cases) }\end{array}$} \\
\hline & $\mathbf{n}$ & $\%$ & $\mathbf{n}$ & $\%$ \\
\hline \multicolumn{5}{|l|}{ Age (years) } \\
\hline Range & $15-77$ & & $2|-7|$ & \\
\hline Median & 39.62 & & 46.65 & \\
\hline 19 or less & 12 & 1.9 & 0 & 0 \\
\hline $20-39$ & 309 & 49.5 & 34 & 21.1 \\
\hline $40-59$ & 262 & 42.0 & 119 & 73.9 \\
\hline 60 or more & 41 & 6.6 & 8 & 5.0 \\
\hline \multicolumn{5}{|l|}{ Education } \\
\hline High school or less & 394 & 63.1 & 108 & 67.1 \\
\hline College or more & 230 & 36.9 & 53 & 32.9 \\
\hline \multicolumn{5}{|l|}{ Marital status } \\
\hline Married & 413 & 66.2 & 127 & 78.9 \\
\hline Single & 155 & 24.8 & 13 & 8.0 \\
\hline Divorced & 33 & 5.3 & 12 & 7.5 \\
\hline Widowed & 23 & 3.7 & 9 & 5.6 \\
\hline \multicolumn{5}{|l|}{ Body mass index } \\
\hline I 8.4 or less & 20 & 3.2 & 3 & 1.9 \\
\hline $18.5-24.9$ & 371 & 59.5 & 76 & 47.2 \\
\hline $25-29.9$ & 169 & 27.1 & 56 & 34.8 \\
\hline 30 or more & 64 & 10.3 & 26 & 16.1 \\
\hline \multicolumn{5}{|l|}{ Age at menarch (years) } \\
\hline 12 or less & 312 & 50.0 & 81 & 50.0 \\
\hline 13 or more & 312 & 50.0 & 80 & 50.0 \\
\hline \multicolumn{5}{|l|}{ Number of pregnancies } \\
\hline 0 & 198 & 31.7 & 21 & 13.0 \\
\hline I & 156 & 25.0 & 54 & 33.5 \\
\hline 2 & 163 & 26.1 & 50 & 31.1 \\
\hline 3 or more & 107 & 17.1 & 36 & 22.4 \\
\hline \multicolumn{5}{|l|}{ Number of deliveries } \\
\hline 0 & 223 & 35.7 & 28 & 17.4 \\
\hline 1 & 163 & 26.1 & 60 & 37.3 \\
\hline 2 or more & 238 & 38.1 & 73 & 45.3 \\
\hline \multicolumn{5}{|l|}{ Miscarriage } \\
\hline Total & 426 & & 140 & \\
\hline No & 334 & 78.4 & 105 & 75.0 \\
\hline Yes & 92 & 21.6 & 35 & 25.0 \\
\hline \multicolumn{5}{|l|}{ Cesarean section } \\
\hline Total & 401 & & 133 & \\
\hline No one & 321 & 80.0 & 109 & 81.9 \\
\hline One or more & 80 & 20.0 & 24 & 18.1 \\
\hline \multicolumn{5}{|l|}{ Contraception } \\
\hline Combined pill & 207 & 33.2 & 29 & 18.0 \\
\hline Progestin pill or hormonal IUD & 54 & 8.7 & 16 & 9.9 \\
\hline Other & 363 & 58.1 & 116 & 72.1 \\
\hline \multicolumn{5}{|l|}{ Presenting symptom } \\
\hline Screening (asymptomatic) & 197 & 31.6 & 47 & 29.2 \\
\hline Metrorrhagia & 67 & 10.7 & 25 & 15.5 \\
\hline Menorrhagia & 15 & 2.4 & 11 & 6.8 \\
\hline Pelvic pain & 61 & 9.8 & 20 & 12.4 \\
\hline Vulvar symptoms & 66 & 9.6 & 13 & 8.1 \\
\hline Breast symptoms & 47 & 7.5 & 12 & 7.5 \\
\hline Leukorrhea & 36 & 5.8 & 6 & 3.7 \\
\hline Contraception counseling & 31 & 5.0 & 5 & 3.1 \\
\hline Infertility counseling & 21 & 3.4 & 0 & 0 \\
\hline Other & 89 & 9.3 & 22 & 13.7 \\
\hline
\end{tabular}

Abbreviation: IUD, intrauterine device.
Table 2 Clinical and ultrasound uterus exploration data (624 cases)

\begin{tabular}{lll}
\hline Clinical and ultrasound data & N & $\%$ \\
\hline Uterine size at gynecological examination & & \\
$\quad$ Normal size & 518 & 83.0 \\
Uterine enlargement & 106 & 17.0 \\
Uterine leiomyoma at ultrasound & & \\
$\quad$ Yes & 161 & 25.8 \\
$\quad$ No & 463 & 74.2 \\
Number of leiomyomas at ultrasound & & \\
(I6I women) & & \\
Single & 80 & 49.7 \\
Multiple & 81 & 50.3 \\
Dimension of largest leiomyoma at ultrasound & & \\
(I6I women) & & \\
$<20 \mathrm{~mm}$ & 79 & 49.1 \\
$20-29 \mathrm{~mm}$ & 43 & 26.7 \\
$30-39 \mathrm{~mm}$ & 18 & 11.2 \\
$40-49 \mathrm{~mm}$ & $1 \mathrm{I}$ & 6.8 \\
$>50 \mathrm{~mm}$ & 10 & 6.2 \\
Previous patient knowledge about leiomyoma & & \\
(I6I women) & & \\
Yes & 99 & 61.5 \\
No & 62 & 38.5 \\
\hline
\end{tabular}

pelvic ultrasonography, ${ }^{13,20,21}$ with, as expected, different results.

Kratochwil et a ${ }^{22}$ introduced ultrasound imaging of feminine pelvic organs in 1972. In 1980, Muram et a ${ }^{23}$ defined criteria for UL identification with TVS as a relatively spherical mass that is echogenically different from the surrounding myometrium. Since then, TVS has become the most noninvasive, lowest-cost, and widespread method for evaluation of uterine pathology, with highly accurate performance. ${ }^{14-16}$ The main disadvantage of ultrasound is that it is an operatorand device-dependent technique. ${ }^{24}$ In order to improve UL diagnosis accuracy, saline contrast sonohysterography and three-dimensional ultrasound have been proposed, although with conflicting results. ${ }^{24,25}$ Nowadays, two-dimensional pelvic ultrasonography remains the best method for routine detection of ULs. ${ }^{24,25}$ Ultrasonography has been shown to be an insufficient method of myoma mapping, and magnetic resonance imaging should preferred for surgical therapy planning. ${ }^{25}$

In the present study, we found a $25.8 \%$ overall prevalence of UL, with the highest prevalence (45.4\%) in women aged 39-50 years, which is in accordance with previous ultrasound-based studies. ${ }^{13,20,26}$ Multiple ULs were present in $50.1 \%$ of cases, which is lower than that reported in surgical specimens by Cramer and Patel $(84 \%) .{ }^{18}$ In contrast to Cramer and Patel's findings, only $49.1 \%$ patients had a UL larger than $20 \mathrm{~mm}$. A previous diagnosis of UL had been made in $99(61.5 \%)$ patients, who were in watchful waiting 
Table 3 Univariate analysis of demographic and clinical characteristics between patients with and without sonographic diagnosis of uterine leiomyoma

\begin{tabular}{|c|c|c|c|}
\hline \multirow[t]{2}{*}{$\begin{array}{l}\text { Demographic and } \\
\text { clinical data }\end{array}$} & \multicolumn{2}{|c|}{$\begin{array}{l}\text { Uterine leiomyoma } \\
\text { at ultrasound }\end{array}$} & \multirow[t]{2}{*}{$P$-value } \\
\hline & No & Yes & \\
\hline \multicolumn{4}{|l|}{ Age (years) } \\
\hline 19 or less & $100.0 \%$ & $0.0 \%$ & 0.0001 \\
\hline $20-39$ & $89.0 \%$ & $11.0 \%$ & \\
\hline $40-59$ & $54.6 \%$ & $45.4 \%$ & \\
\hline 60 or more & $80.5 \%$ & $19.5 \%$ & \\
\hline \multicolumn{4}{|l|}{ Education } \\
\hline High school or less & $72.6 \%$ & $27.4 \%$ & 0.134 \\
\hline College or more & $77.0 \%$ & $23.0 \%$ & \\
\hline \multicolumn{4}{|l|}{ Marital status } \\
\hline Married & $69.2 \%$ & $30.8 \%$ & $<0.0001$ \\
\hline Other & $83.9 \%$ & $16.1 \%$ & \\
\hline \multicolumn{4}{|l|}{ Body mass index } \\
\hline 18.4 or less & $85.7 \%$ & $14.3 \%$ & 0.002 \\
\hline $18.5-24.9$ & $79.2 \%$ & $20.8 \%$ & \\
\hline $25-29.9$ & $66.9 \%$ & $33.1 \%$ & \\
\hline $30-34.9$ & $62.3 \%$ & $37.7 \%$ & \\
\hline 35 or more & $54.5 \%$ & $45.5 \%$ & \\
\hline \multicolumn{4}{|l|}{ Age at menarch (years) } \\
\hline 12 or less & $74.0 \%$ & $26.0 \%$ & 0.500 \\
\hline 13 or more & $74.4 \%$ & $25.6 \%$ & \\
\hline \multicolumn{4}{|l|}{ Pregnancy } \\
\hline No & $89.4 \%$ & $10.6 \%$ & $<0.0001$ \\
\hline Yes & $67.1 \%$ & $32.9 \%$ & \\
\hline \multicolumn{4}{|l|}{ Number of pregnancies } \\
\hline I & $65.4 \%$ & $34.6 \%$ & $0.74 I$ \\
\hline 2 & $69.3 \%$ & $30.7 \%$ & \\
\hline 3 or more & $66.4 \%$ & $33.6 \%$ & \\
\hline \multicolumn{4}{|l|}{ Delivery } \\
\hline No & $87.4 \%$ & $12.6 \%$ & $<0.0001$ \\
\hline Yes & $66.8 \%$ & $33.2 \%$ & \\
\hline \multicolumn{4}{|l|}{ Number of deliveries } \\
\hline 1 & $63.2 \%$ & $36.8 \%$ & 0.120 \\
\hline 2 or more & $69.3 \%$ & $30.7 \%$ & \\
\hline \multicolumn{4}{|l|}{ Miscarriage } \\
\hline No & $68.6 \%$ & $33.7 \%$ & 0.143 \\
\hline Yes & $62.0 \%$ & $38.0 \%$ & \\
\hline \multicolumn{4}{|l|}{ Cesarean section } \\
\hline \multicolumn{4}{|l|}{ (40I women) } \\
\hline No one & $66.3 \%$ & $33.7 \%$ & 0.360 \\
\hline One or more & $69.2 \%$ & $30.8 \%$ & \\
\hline \multicolumn{4}{|l|}{ Contraception } \\
\hline Combined pill & $85.9 \%$ & $14.1 \%$ & $<0.0001$ \\
\hline Progestin pill & $70.4 \%$ & $29.6 \%$ & \\
\hline \multicolumn{4}{|l|}{ or hormonal IUD } \\
\hline Other & $69.6 \%$ & $30.4 \%$ & \\
\hline \multicolumn{4}{|l|}{ Menopause } \\
\hline No & $76.1 \%$ & $23.9 \%$ & 0.011 \\
\hline Yes & $64.4 \%$ & $35.6 \%$ & \\
\hline \multicolumn{4}{|l|}{ Presenting symptom } \\
\hline Menorrhagia & $26.7 \%$ & $73.3 \%$ & $<0.0001$ \\
\hline Metrorrhagia & $63.2 \%$ & $36.8 \%$ & \\
\hline Pelvic pain & $64.3 \%$ & $35.7 \%$ & \\
\hline Other & $78.8 \%$ & $21.2 \%$ & \\
\hline
\end{tabular}

Abbreviation: IUD, intrauterine device.
Table 4 Presenting symptoms according to number of uterine leiomyomas at ultrasound

\begin{tabular}{llll}
\hline $\begin{array}{l}\text { Presenting } \\
\text { symptom }\end{array}$ & \multicolumn{2}{l}{$\begin{array}{l}\text { Uterine leiomyomas } \\
\text { at ultrasound }\end{array}$} & P-value \\
\cline { 2 - 3 } & Multiple & Single & \\
\hline Metrorrhagia & $72.0 \%$ & $28.0 \%$ & 0.018 \\
Menorrhagia & $72.7 \%$ & $27.3 \%$ & \\
Pelvic pain & $55.0 \%$ & $45.0 \%$ & \\
Other & $41.9 \%$ & $58.1 \%$ & \\
\hline
\end{tabular}

management, which has been considered as a safe management option for asymptomatic UL. ${ }^{27,28}$ Except in three cases submitted to resectoscopy for treatment of symptomatic submucous myomas, the main component of the leiomyomas was intramural. A purely intramural myoma represents a temporary status, and its growth is dependent on the existing hormonal conditions of the woman. ${ }^{29}$

Most of the knowledge about demographic and clinical risk factors for UL is based on results of large populations survey studies. Risk factors such as age, ethnicity, education, hormonal factors, diet, physical exercise, oral contraceptives use, childbirth, smoking and tissue injury has been reported, with conflicting results. In accordance with other ultrasoundbased studies, ${ }^{13,20,26}$ after multivariate statistical analysis, we don't found any demographic or clinical risk factor for UL, with exception of age.

The most common symptom of UL is abnormal uterine bleeding, especially menorrhagia. ${ }^{5}$ The mechanism of leiomyoma-associated menorrhagia is unknown, but submucous localization, vascular defects, and impaired endometrial hemostasis have been suggested as possible explanations. ${ }^{30,31}$ Even small ULs without distortion of the endometrial cavity can alter myometrial vascularization and contractibility. A meta-analysis conducted by Benecke et $\mathrm{al}^{32}$ reported that intramural ULs may have a negative impact on fertility. In our series, menorrhagia was significantly associated with multiplicity of ULs, but not with the volume of the largest one, suggesting the importance of factors other than those associated with distortion of the myometrium and endometrial cavity. Extracellular matrix that embed UL cells influence both

Table 5 Presenting symptoms according to size of largest uterine leiomyoma at ultrasound

\begin{tabular}{llll}
\hline $\begin{array}{l}\text { Presenting } \\
\text { symptom }\end{array}$ & \multicolumn{2}{l}{$\begin{array}{l}\text { Size of largest uterine } \\
\text { leiomyoma }\end{array}$} & \multirow{2}{P}{-value } \\
\cline { 2 - 3 } & $<\mathbf{3 ~ c m}$ & $\geq 3 \mathbf{~ c m}$ & \\
\hline Metrorrhagia & $60.0 \%$ & $40.0 \%$ & 0.215 \\
Menorrhagia & $72.7 \%$ & $27.3 \%$ & \\
Pelvic pain & $75.0 \%$ & $25.0 \%$ & \\
Other & $80.0 \%$ & $20.0 \%$ & \\
\hline
\end{tabular}


normal myometrial and UL cells, promoting proliferative activity and decreasing apoptosis..$^{33,34}$ Previous ultrasoundbased studies ${ }^{20-35}$ have reported that the presence, number, and volume of leiomyomas are unrelated to abnormalities in the menstrual cycle. Other studies, ${ }^{36,37}$ but not all, ${ }^{38}$ suggest that menstrual symptoms are related to tissue layer location in the uterine wall and with the axial position of leiomyomas. In our study, multiplicity of ULs was significantly related to abnormal uterine bleeding (menorrhagia and metrorrhagia) as a presenting symptom.

Currently, most women with menstrual disorders and multiple ULs are scheduled for medical therapy followed by hysterectomy or myomectomy. ${ }^{39}$ Hysterectomy seems a good option when childbearing wishes have been fulfilled; ${ }^{39}$ but it is not devoid of risks, morbidity and mortality as for any surgical procedure. Myomectomy is indicated for those women who wish to retain their fertility. ${ }^{39}$ The major disadvantage of surgical myomectomy is leiomyoma recurrence. In next 5 years, more than one-third of that women submitted to myomectomy will need additional surgical intervention for treatment of newly developed ULs. ${ }^{40}$ Minimally invasive procedures, such as laparoscopic myolysis, uterine artery embolization, uterine fibroid embolization, and magnetic resonance-guided focused ultrasound, as standard practice for treatment of symptomatic multiple ULs are currently limited. ${ }^{41}$ It seems obvious that new treatments better than surgical approaches are needed for the management of symptomatic UL.

In recent years, intense scientific research has brought new insights on UL biology. The development of ULs has been shown to be dependent of sex steroids, especially progesterone, ${ }^{42,43}$ and many leiomyoma-related growth factors have been identified, including epidermal growth factor, platelet-derived growth factor, transforming growth factor beta, insulin-like growth factor, activin, and myostatin. We speculate that, in patients with multiple ULs and menstrual disorders, each UL can produce different kinds of growth factors or other biological mediators that may have additive negative effects on the myometrial and endometrial environment.

Discovery of selective progesterone receptor modulators (SPRMs) has provided a new paradigm for treatment of symptomatic UL. Antiproliferative, growth factors downregulation, and proapoptotic actions of SPRMs had been reported in vitro studies over cultured leiomyoma cells. ${ }^{43}$ Randomized, placebo-controlled clinical trials have demonstrated that the SPRM ulipristal can suppress menstrual bleeding, restore normal levels of hemoglobin, reduce UL volume, and improve leiomyoma-related symptoms. ${ }^{44,45}$
The main objective of symptomatic UL treatment is to regress symptomatology, because expectant management is suitable for most asymptomatic leiomyomas. ${ }^{27,28}$ It is expected that new therapies for the treatment of UL-associated symptomatology will be developed, based on the growing knowledge of functional aspects and regulatory mechanisms of leiomyoma biology and uterine homeostasis.

\section{Conclusion}

To our knowledge, this is the first population study conducted in Portugal to assess the prevalence and demographic and clinical factors associated with the diagnosis of UL by ultrasound. In our Portuguese population, the prevalence of uterine leiomyoma increases with age, and was similar to that reported in literature for White women.

Menorrhagia and metrorrhagia were the more distressing symptoms, especially in patients with multiple ULs diagnosed by TVS. In patients with abnormal uterine bleeding, special attention should be taken to search for multiple leiomyomas during pelvic ultrasound examination.

Further studies are needed to assess the biology and symptomatic impact of multiple versus single ULs, in order to find more efficient therapeutic approaches.

\section{Disclosure}

Publication processing fees for this paper were paid by Gedeon Ritcher. The authors have no other conflicts of interest to report.

\section{References}

1. Walker CL, Stewart EA. Uterine fibroids: the elephant in the room. Science. 2005;308:1589-1592.

2. Schwartz PE, Kelly MG. Malignant transformation of myomas: myth or reality? Obstet Gynecol Clin North Am. 2006;33:183-198.

3. Parker WH. Etiology, symptomatology, and diagnosis of uterine myomas. Fertil Steril. 2007;87:725-736.

4. Wise LA, Palmer JR, Stewart EA, Rosenberg L. Age-specific incidence rates for self-reported uterine leiomyomata in the Black Women's Health Study. Obstet Gynecol. 2005;105:563-568.

5. Buttram VC Jr, Reiter RC. Uterine leiomyoma: etiology, symptomatology and management. Fertil Steril. 1981;36:433-445.

6. Haney AF. Clinical decision making regarding leiomyomata: what we need in the next millennium. Environ Health Perspect. 2000; 108 Suppl 5:835-839.

7. Huyck KL, Panhuysen CI, Cuenco KT, et al. The impact of the race as a risk factor for symptoms severity and age at diagnosis of uterine leiomyomata among affected sisters. Am J Obstet Gynecol. 2008;198(2): 168 , e1.

8. Marshall LM, Spiegelman D, Barbieri RI, et al. Variation in the incidence of uterine leiomyoma among premenopausal women by age and race. Obstet Gynecol. 1997;90:967-973.

9. Vikhlyaeva EM, Khodzhaeva ZS, Fantschenko ND. Familial predisposition to uterine leiomyomas. Int J Gynaecol Obstet. 1995;51:127-131. 
10. Andersen J. Growth factors and cytokines in uterine leiomyomas. Semin Reprod Endocrinol. 1996;14:269-282.

11. Schwartz SM, Marshall LM, Baird DD. Epidemiologic contributions to understanding the etiology of uterine leiomyomata. Environ Health Perspect. 2000;108(5):821-827.

12. Chegini N. Proinflammatory and profibrotic mediators: principal effectors of leiomyoma development as a fibrotic disorder. Semin Reprod Med. 2010;28(3):180-203.

13. Baird DD, Dunson DB, Hill MC, Cousins D, Schectman JM. High cumulative incidence of uterine leiomyoma in black and white women: ultrasound evidence. Am J Obstet Gynecol. 2003;188:100-107.

14. Kurtz AB, Middleton WD. Ultrasound. St Louis, MO: Mosby; 1996.

15. Sauerbrel EE, Nguyen KT, Nolan RL. A Practical Guide to Ultrasound in Obstetrics and Gynecology. 2nd ed. Philadelphia, PA: LippincottRaven; 1998.

16. Callen PW, editor. Ultrasonography in Obstetrics and Gynecology. 5th ed. Philadelphia, PA: Saunders Elsevier; 2007.

17. Downes E, Sikirica V, Gilabert-Estelles J, et al. The burden of uterine fibroids in five european countries. Eur J Obstet Gynecol Reprod Biol. 2010;152(1):95-102.

18. Cramer SF, Patel A. The frequency of uterine leiomyomas. Am J Clin Pathol. 1990;94:435-438.

19. Micheletti AR, Macedo AC, Silva GB, et al. Benign and malignant neoplasias in 261 necropsies for HIV-positive patients in the period of 1989 to 2008. Rev Inst Med Trop Sao Paulo. 2011;53(6):3019-314.

20. Marino JL, Eskenazi B, Warner M, et al. Uterine leiomyoma and menstrual cycle characteristics in a population-based cohort study. Hum Reprod. 2004;19:2350-2355.

21. Marsh EE, Ekpo GE, Cardozo ER, Brocks M, Dune T, Cohen LS. Racial differences in fibroids prevalence and ultrasound findings in asymptomatic young women (18-30 years old): a pilot study. Fertil Steril. 2013;99:1951-1957.

22. Kratochwil A, Urban G, Friedrich F. Ultrasonic tomography of the ovaries. Ann Chir Gynaecol Fenn. 1972;61(4):211-214.

23. Muram D, Gillieson M, Walters JH. Myomas of the uterus in pregnancy: ultrasonographic follow-up. Am J Obstet Gynecol. 1980;138:16-19.

24. Vitiello D, McCarthy S. Diagnostic imaging of myomas. Obstet Gynecol Clin North Am. 2006;33:85-95.

25. Stamatopoulos CP, Mikos T, Grimbizis GF, et al. Value of magnetic resonance imaging in diagnosis of adenomyosis and myomas of the uterus. J Minim Invasive Gynecol. 2012;19(5):620-626.

26. Borgfeldt C, Andolf E. Transvaginal ultrasonographic findings in the uterus and endometrium: low prevalence of leiomyoma in a random sample of women age 25-40 years. Acta Obstet Gynecol Scand. 2000;79(3):202-207.

27. Carlson KJ, Miller BA, Fowler FJ Jr. The Maine Women's Health Study: II. Outcomes of nonsurgical management of leiomyomas, abnormal bleeding, and chronic pelvic pain. Obstet Gynecol. 1994;83(4): 566-572.

28. Farquhar C, Arroll B, Ekeroma A, et al. An evidence-based guidance for the management of uterine fibroids. Aust NZ J Obstet Gynaecol. 2001;14:125-140.

29. Bettocchi S, Siristatidis C, Pontrelli G, et al. The destiny of myomas: should we treat small submucous myomas in women of reproductive age? Fertil Steril. 2008;90(4):905-910.
30. Dubuisson JB, Chapron C, Fauconnier A, Kreiker G. Laparoscopic myomectomy and myolysis. Curr Opin Obstet Gynecol. 1997;9(4): 233-238.

31. Andersen J. Factors in fibroid growth. Baillieres Clin Obstet Gynaecol. 1998;12(2):225-243.

32. Benecke C, Kruger TF, Siebert TI, Van der Merwe JP, Steyn DW. Effect of fibroids on fertility in patients undergoing assisted reproduction. A structured literature review. Gynecol Obstet Invest. 2005;59: 225-230.

33. Zaitseva M, Vollenhoven BJ, Rogers PA. In vitro culture significantly alters gene expression profiles and reduces differences between myometrial and fibroid smooth muscle cells. Mol Hum Reprod, 2006;12:187-207.

34. Ciarmela P, Islam MS, Reis FM, et al. Growth factors and myometrium: biological effects in uterine fibroids and possible clinical implications. Hum Reprod Update. 2011;17(6):772-790.

35. Faerstein E, Szklo M, Rosenshein N. Risk factors for uterine leiomyoma: a practical-based case control study. I. African-American heritage, reproductive history, body size, and smoking. Am J Epidemiol. 2001; 153(1):1-10.

36. Clevenger-Hoeft M, Syrop CH, Stovall DW, Van Voorhis BJ. Sonohysterography in premenopausal women with and without abnormal bleeding. Obstet Gynecol. 1999;94:516-520.

37. Akkad AA, Habiba MA, Ismail N, Abrams K, al-Azzawi F. Abnormal uterine bleeding on hormonal replacement: the importance of intrauterine structural abnormalities. Obstet Gynecol. 1995;86(3):330-334.

38. Wegienka G, Baird DD, Hertz-Picciotto I, et al. Self-reported heavy bleeding associated with uterine leiomyomata. Obstet Gynecol. 2003; 101(3):431-437.

39. Duhan N. Current and emerging treatments for uterine myoma - an update. Int J Womens Health. 2011;3:231-241.

40. Stewart EA, Faur AV, Wise LA, Reilly RJ, Harlow BL. Predictors of subsequent surgery for uterine leiomyomas after abdominal myomectomy. Obstet Gynecol. 2002;99:426-432.

41. Sharp HT. Assessment of new technology in the treatment of idiopathic menorrhagia and uterine leiomyomata. Obstet Gynecol. 2006;108:990-1003.

42. Schweppe KW. Long-term use of progestogens - effects on endometriosis, adenomyosis and myomas. Gynecol Endocrinol. 2007;23 Suppl 1: 17-21.

43. Maruo T, Ohara N, Yoshida S, et al. Lessons learned from the preclinical drug discovery of asoprisnil and ulipristal for non-surgical treatment of uterine leiomyomas. Expert Opin Drug Discov. 2011;6:897-911.

44. Levens ED, Potlog-Nahari C, Armstrong AY. CDB-2914 for uterine leiomyomata treatment: a randomized controlled trial. Obstet Gynecol. 2008;111:1129-1136.

45. Nieman LK, Blocker W, Nansel T, et al. Efficacy and tolerability of CDB-2914 treatment for symptomatic uterine fibroids: a randomized, double blinded, placebo-controlled, phase IIb study. Fertil Steril. 2011;95:767-772.
International Journal of Women's Health

\section{Publish your work in this journal}

The International Journal of Women's Health is an international, peerreviewed open-access journal publishing original research, reports, editorials, reviews and commentaries on all aspects of women's healthcare including gynecology, obstetrics, and breast cancer. The manuscript management system is completely online and includes

\section{Dovepress}

a very quick and fair peer-review system, which is all easy to use Visit http://www.dovepress.com/testimonials.php to read real quotes from published authors. 